\title{
ASCORBIC AND SALICYLIC ACIDS AS WELL AS SEAWEED AND YEAST EXTRACTS ALTERED STRESS-RELATED METABOLITES AND ITS QUALITY OF Turnitn AND ENHANCED YIELD AND ITS QUALITY OF SALT- STRESSED SOYBEAN ( GLYCINE MAX [L.] MERRILL ).
M. Ibrahim ${ }^{1}$;
M.I. Atta $^{2}$ and \\ Saker, M.T.; Heba \\ M.A. AbdEl-Aal ${ }^{2}$ \\ 1 Botany Department, Faculty of Agriculture, Mansoura University, Mansoura, Egypt, \\ ${ }^{2}$ Seed Technology Research Dept., Field Crops Research Institute, Agric. Research Center, Egypt
}

\begin{abstract}
The alleviation effects of ascorbic (AsA) and salicylic (SA) acids as well as seaweed (SWE) and yeast (YE) extracts against salinity stress on soybean plant were evaluated. Two experiments were conducted at the greenhouse and labs. of the Agric. Bot. Dept., Fac. of Agric., Mansoura Univ., and Seed Technology Research Unit, Field Crops Research Institute, Agric. Research Center, during the two growing Seasons 2010 and 2011. Salt stress was imposed by dissolving natural salt crust in tap water to obtain saline irrigation water at $5000,6000,7000,8000$ and $9000 \mathrm{mgL}^{-1}$.

Results indicated that all tested substances partially restored the salinity induced decrease in seed yield, with AsA and YE were the most effective in this respect. Total phenols, proline and endogenous ascorbic acid contents were increased in response to either salinity stress, stress alleviators or their interaction. The ratio between $\mathrm{Na}$ and $\mathrm{K}$ in both shoots and roots was decreased in response to stress alleviators. In addition, seed oil and protein contents were increased in saltstressed, stress alleviators- treated plants compared with salt-stressed only plants. In addition, results indicated that the alleviative effect of the applied stress mitigators was evident not only on salt-stressed plants but also on their descendant seeds where their germination, vigour, and seedling establishment were enhanced. It is concluded that AsA, SA, SWE and YE, preferably the first and the latter, could be used to maintain yield of soybean growing in salt-affected soils.

Keywords: soybean, Glycine max; salt- stress tolerance; ascorbic acid; salicylic
\end{abstract} acid ; seaweed extract; yeast extract.

\section{INTRODUCTION}

Soybean (Glycine max [L.] Merrill) is a legume species native to East Asia, widely grown for its edible seeds which has numerous uses. Soybeans produce significantly more protein per acre than most other legumes. Soybean protein is an ingredient in many meat and dairy analogues. The oil is used in many industrial applications. Seeds contain significant amounts of phytic acid, alpha-linolenic acid and isoflavones. Abiotic stress including salinity, drought, excess irrigation, high or low temperature, and heavy metals are common sources of stress which affects plant growth, development, 
structure, as well as physiological and biochemical processes. Salinity is one of the major stresses and can severely limit plant growth and productivity (Chernane et al., 2015). In Egypt, salinity is a serious problem particularly in the Delta. Sixty percent of the cultivated lands of Northern Delta region are salt-affected, twenty percent of the Southern Delta and Middle Egyptian region and twenty five percent of the Upper Egypt region are salt-affected soils (Gehad, 2003).

Most of the crop species are glycophytes, and generally show limited growth and development due to salinity. Salt stress affects major plant processes such as photosynthesis, protein synthesis and lipid metabolism (Parvaiz and Satyawati, 2008). During salt stress, generation of reactive oxygen species (ROS) is accelerated, leading to oxidative stress. ROS interact with many cellular components, causing significant damage to membranes and other cellular structures and induce oxidative stress (Parvaiz and Satyawati 2008). In most studies concerning the effects of salinity on plants salinity stress is generated through the use of $\mathrm{NaCl}$ as the Salinization agent, which represent an artificial salinized medium. Authentic effects of more naturally saline medium resembling sea water and containing multiple cations and anions is less conducted and poorly-understood.

Plants have evolved a ROS-scavenging network, composed of enzymatic and non-enzymatic antioxidants for maintaining the levels of ROS under tight control. However, under stressful conditions, generation of ROS surpass the plant antioxidant system's ability to scavenge them. In such situation, external measures are needed to strengthen the defense mechanisms and maintain plant growth and productivity. Several compounds with different biochemical effects have been tried to mitigate stress effects on various plant species and mostly applied either as seed soaking, foliar spray or both combined. From these compounds AsA (Dehghan, et al., 2011), SA (Arfan, et al., 2006; Arfan 2009 ; Kabiri et al., 2014), seaweed extract (Abdel Aziz et al., 2011; Mansori et al., 2014; Chernane et al., 2015), and YE (Hammad and Ali, 2014; Ibrahim, 2014), have been used to induce plant tolerance to various environmental stressors. However, Effects of these compounds on salt-stressed soybean is less understood. In most studies conducted to evaluate the effects of stress alleviators on plants, their effects were invariably evaluated through monitoring some features of F0 plants including their seed yield. As seeds are the antecedents to the F1 generation, their quality attributes that indicate the degree by which they give a healthy F1 generation are invariably ignored which represent a gap in the previous studies. Therefore, the present investigation aimed to study the effects of some stress modulators (SMs) on:

1. The metabolic adjustment of salt-stressed soybean (cv. Giza 111) that contribute to the plant's salt stress tolerance.

2. The establishment of the $\mathrm{F} 1$ generation via estimating certain quality parameters of F0's seed germination and seedling growth.

The hypothesis on which the study stands is that under salinity stress, these SMs will modulate salinity-induced responses towards acquiring salt stress tolerance. 


\section{MATERIALS AND METHODS}

\section{Experimental conditions}

Experiments were carried out at the Agricultural Botany Dept., Fac. of Agric., Mansoura Univ. and Seed Technology Research Dept., Agric. Res. Center, Ministry of Agric., Egypt during 2010 and 2011 seasons. Seeds of Giza 111 cultivar were obtained from Seed Production Station's Central Administration, Dakahlia Governorate, Egypt. In the two growing seasons, rhizobium inoculated seed sowing was carried out on May, $15^{\text {th }}$ in pots (40 $\mathrm{cm}$ inner diam.) containing $15 \mathrm{~kg}$ of air dried soil at the rate of 6 seeds/pot. Physical and chemical characteristics of the experimental soil are shown in Table (1). Thinning was made 20 days after sowing (DAS) to leave 4 uniform seedlings/ pot. The pots were arranged in a randomized complete block design. Each pot received calcium superphosphate $\left(15.5 \% \mathrm{P}_{2} \mathrm{O}_{5}\right)$, at a rate of $150 \mathrm{~kg} / \mathrm{fed}$ before sowing; nitrogen in the form of urea $(46.5 \% \mathrm{~N})$ at the rate of $50 \mathrm{~kg} / \mathrm{fed}$, divided into two equal doses and supplied at 20 and 30 DAS and potassium sulphate $\left(48 \% \mathrm{k}_{2} \mathrm{O}\right)$ at the rate of $50 \mathrm{~kg} / \mathrm{fed}$, applied at the beginning of the flowering stage.

Six levels of salinity i.e : 1) Tap water as a control $\left.\left(320 \mathrm{mgL}^{-1}\right), 2\right)$ $5000 \mathrm{mgL}^{-1}$, 3) $6000 \mathrm{mgL}^{-1}$, 4) $7000 \mathrm{mgL}^{-1}$, 5) $8000 \mathrm{mgL}^{-1}$ and 6) $9000 \mathrm{mgL}^{-1}$ were prepared by dissolving known weight of natural salt crust in tap water (artificial seawater).

Table (1) : Physical ${ }^{* *}$ and chemical ${ }^{* * *}$ characteristics of the experimental soil

\begin{tabular}{|c|c|c|c|c|c|c|c|c|c|c|c|}
\hline Sand & Silt & Clay & $\mathrm{CaCo}_{3}$ & $\mathrm{pH}$ & $\begin{array}{c}E C \\
\left(\mathrm{dsm}^{-1}\right)\end{array}$ & O.M. & $\begin{array}{c}\mathbf{N} \\
(\mathrm{ppm})\end{array}$ & $\begin{array}{c}\mathrm{K} \\
(\mathrm{ppm})\end{array}$ & $\begin{array}{c}\mathbf{P} \\
(\mathrm{ppm})\end{array}$ & $\begin{array}{c}\mathrm{Na} \\
\left(\mathrm{meqL}^{-1}\right)\end{array}$ & $\begin{array}{c}\mathrm{Cl} \\
\text { meqL }^{-1} \text { ) }\end{array}$ \\
\hline 22.1 & 33 & 44 & 2.5 & 8.1 & 0.43 & 1.92 & 14.4 & 227 & 11.76 & 0.83 & 1.1 \\
\hline
\end{tabular}

Seeds were soaked for 3 hours in the solutions of the stress modulators (SMs) used before inoculation and sowing. In addition, the plants raised from soaked seeds were sprayed with the same SMs at two physiological stages (30 and 60 DAS). The used SMs treatments were 1) Tap water, as a control; 2) Ascorbic acid (AsA), $250 \mathrm{mgL}^{-1}$; 3) Salicylic acid (SA), $250 \mathrm{mgL}^{-1}$; 4) Seaweed extract (SWE), $1000 \mathrm{mgL}^{-1}$ and 5) yeast extract (YE), $1000 \mathrm{mgL}^{-1}$. Each treatment had four replications. Components of YE are shown in Table (2) according to Mahmoued (2001).

Investigated parameters

Biochemical constituents

Samples were taken at 75 DAS to estimate the following biochemical parameters:

Total phenols:

The assay was based on the method of Toivonen and Stan, (2004). A sample of $10 \mathrm{mg}$ was extracted in $1.2 \mathrm{M}$ of $\mathrm{HCl}$ and $50 \% \mathrm{Me}-\mathrm{OH}$ by heating at $80{ }^{\circ} \mathrm{C}$ for $3 \mathrm{~h}$. After centrifugation at $18000 \mathrm{~g}, \quad 0.1 \mathrm{~mL}$ of 
supernatant was mixed with $0.1 \mathrm{~mL}$ of Folin- ciocalteu reagent and $0.5 \mathrm{~mL}$ of $20 \% \mathrm{Na}_{2} \mathrm{CO}_{3}$ and allowed to stand in the dark for $15 \mathrm{~min}$. Absorbance was measured at $725 \mathrm{~nm}$ with gallic acid as a standard and the total phenolic content was calculated as gallic acid equivalent.

Table (2): Chemical analysis of yeast extract

\begin{tabular}{|l|c|l|c|}
\hline $\begin{array}{l}\text { Amino acid } \mathbf{~ m g / 1 0 0 g} \\
\text { dry weight }\end{array}$ & $\begin{array}{l}\text { Vitamins and Carbohydrates } \\
\text { mg/100g dry weight }\end{array}$ \\
\hline Arginine & 1.99 & Vit.B1 & 2.23 \\
\hline Histidine & 2.63 & Vit.B2 & 1.33 \\
\hline Isoleucine & 2.31 & Vit.B6 & 1.25 \\
\hline leucine & 3.09 & Vit.12 & 0.15 \\
\hline Lysine & 2.95 & Thimain & 2.71 \\
\hline Methionine & 0.72 & Riboflavin & 4.96 \\
\hline Phenyl alanine & 2.01 & Inositol & 0.26 \\
\hline Threonine & 2.09 & Biotin & 0.09 \\
\hline Tryptophan & 0.45 & Nicotinic acid & 39.88 \\
\hline Valine & 2.19 & Panthothenic acid & 19.56 \\
\hline Glutamic acid & 2.00 & P amino benzoic acid & 9.23 \\
\hline Serine & 1.59 & Folic acid & 4.36 \\
\hline Aspartic acid & 1.33 & Pyridoxine & 2.90 \\
\hline Cystine & 0.23 & Total carbohydrates & 23.20 \\
\hline Proline & 1.53 & Glucose & 13.33 \\
\hline Tyrosine & 1.49 & Glun & \multicolumn{2}{|l}{} \\
\hline
\end{tabular}

Proline content: according to the method of Bates, et al. (1973), approx. 300 $\mathrm{mg}$ of dry leaf tissues were homogenized in $10 \mathrm{~mL}$ of $3 \%(\mathrm{w} / \mathrm{v})$ aqueous sulphosalicylic acid and filtered. To $2 \mathrm{~mL}$ of the filtrate, $2 \mathrm{~mL}$ of acid ninhydrin was added, followed by the addition of $2 \mathrm{~mL}$ of glacial acetic acid and boiling for $60 \mathrm{~min}$. The mixture was extracted with toluene and free proline was quantified spectrophotometrically at $520 \mathrm{~nm}$ from the organic phase.

Nitrogen content: The improved Kjeldahl method of A.O.A.C. (1980) was employed.

Dry seed sample of $0.5 \mathrm{~g}$ weight was digested with sulphuric acid and hydrogen peroxide mixture. Distribution was carried out with $40 \% \mathrm{NaOH}$ and ammonium was received in $4 \%$ boric acid solution. The distributes were then titrated with $0.02 \mathrm{~N} \mathrm{HCl}$ using the mixed methyl red-bromocresol green indicator. Nitrogen concentration was calculated as percentage on the dry matter basis Seed protein:

Protein percent was calculated by multiplying the percentage of total nitrogen by the factor of 6.25 .

Oil seed content:

A samples of $5 \mathrm{~g}$ of dried seeds was extracted with Petroleum ether using Soxholet's apparatus according to the A.O.A.C. (1980) method.

Total ascorbic acid (AsA):

As A content was determined using the 2,6 dichlorophenol indophenol method as described by Ranganna (1979). 


\section{Potasium and sodium contents}

$\mathrm{Na}$ and $\mathrm{K}$ percent in shoots and roots of soybean plant was estimated Flamephotometrically according to Peterburgski (1968) using Jenway Flamephotometer.

\section{FO's seed quality parameters}

For assessing quality of the seeds resulting from the pot experiment, a random sample of 400 seeds per treatment were sown on filter paper in sterilized Petri-dishes (14-cm diameter ), 25 seeds/dish. Seed quality tests were done according the rules of International Seed Testing Association (ISTA, 1985)

\section{Statistical Analysis:}

Data were subjected to ANOVA statistical analysis as described by Gomez and Gomez (1984). Treatment means were compared using the least significant difference (L.S.D.) at 0.05 level of probability. Similar results were recorded during the two growing seasons of the experiment so, only the data of the first season were presented.

\section{RESULTS}

Proline, total phenols and AsA contents:

Salinity levels above $5000 \mathrm{mgL}^{-1}$ and all tested SMs as well as their interactions increased proline and phenols (Table 3 ) as well as ASA contents (Table 4). The highest increases were recorded in AsA-treated plants stressed with salinity at $9000 \mathrm{mgL}^{-1}$

Table (3): Effect of salinity stress levels and SMs as well as their interactions on proline $(\mathrm{mg} / \mathrm{g} \mathrm{D} . \mathrm{Wt})$ and total phenols $(\mathrm{mg}$ $/ 100 \mathrm{~g} \mathrm{~F}$.Wt) contents in shoots soybean plants.

\begin{tabular}{|c|c|c|c|c|c|c|c|c|c|c|c|c|c|c|}
\hline \multirow{3}{*}{ SMs (B) } & \multicolumn{14}{|c|}{ Salinity levels $(\mathrm{mg} / \mathrm{l})(\mathrm{A})$} \\
\hline & \multicolumn{6}{|c|}{\begin{tabular}{|l|l|l|l|l|l|}
320 & 5000 & 6000 & 7000 & 8000 & 9000 \\
\end{tabular}} & \multirow[b]{2}{*}{$\stackrel{2}{5}$} & \multirow[t]{2}{*}{320} & \multicolumn{5}{|c|}{\begin{tabular}{|l|l|l|l|l|l|l|} 
& 5000 & 6000 & 7000 & 8000 & 9000
\end{tabular}} & \multirow{2}{*}{ 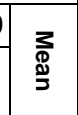 } \\
\hline & \multicolumn{6}{|c|}{ Proline content } & & & \multicolumn{5}{|c|}{ Total phenols content } & \\
\hline Tap water & 2 & 6.28 & & & & & 6.26 & 43.2 & & & 72.8 & & & \\
\hline IsA & 72 & 7 & 7. & & 5 & & 7.58 & 69.6 & 4 & & 8 & & & \\
\hline A & 4.68 & 6.42 & 6.75 & 6.92 & 7.20 & 7. & 6.65 & 47.3 & 0 & 73.6 & 77 & |00.0 & 10 & $7 i$ \\
\hline SWE & & 6.64 & 6.90 & 1 & 1 & 8 & 6.86 & 56.8 & 1 & 81 & 82.5 & 83.9 & 85.7 & 78 \\
\hline VE & 63 & 7.22 & 7.32 & 7.47 & 7.94 & 8.46 & 34 & 63.9 & 81.5 & 82.7 & 83.6 & 84.5 & 86.2 & 80 \\
\hline Mean & 4.90 & 6.77 & 6.99 & 7.18 & 7.55 & 8.24 & & 56.2 & 75.8 & 78.1 & 80.7 & 83.1 & 84.8 & \\
\hline SD at $5 \%$ & A: & & B: & 0.8 & AXB & 1.2 & & & 2.4 & & 2.1 & AXB & $3: 3.3$ & \\
\hline
\end{tabular}


Table (4): Effect of salinity stress levels and SMs as well as their interactions on AsA content ( $\mathrm{mg} / 100 \mathrm{~g} \mathrm{F.Wt}$ ) in shoots of soybean plants.

\begin{tabular}{|c|c|c|c|c|c|c|c|}
\hline \multirow{2}{*}{$\begin{array}{l}\text { SMs (B) } \\
\text { Antioxidant(B) }\end{array}$} & \multicolumn{7}{|c|}{ Salinity levels $(\mathrm{mg} / \mathrm{l})(\mathrm{A})$} \\
\hline & 320 & 5000 & 6000 & 7000 & 8000 & 9000 & Mean \\
\hline Tap water & 110 & 151 & 158 & 167 & 178 & 184 & 158 \\
\hline AsA & 146 & 213 & TYY & 257 & 298 & 310 & 241 \\
\hline SA & 121 & 191 & $r \ldots$ & 229 & 267 & 276 & 214 \\
\hline SWE & $1 \% \Lambda$ & 199 & $r \cdot \Lambda$ & $r \leq T$ & r人t & 191 & TYA \\
\hline \begin{tabular}{|l|}
$Y E$ \\
\end{tabular} & $1 \leq 1$ & 206 & 214 & 254 & 290 & 299 & 234 \\
\hline Mean & 131 & 192 & 200 & 231 & 264 & 272 & \\
\hline LSD at $5 \%$ & \multicolumn{2}{|c|}{ A: 16} & \multicolumn{2}{|c|}{ B: 12} & \multicolumn{2}{|c|}{ AXB: 28} & \\
\hline
\end{tabular}

$\mathrm{Na}$ and $\mathrm{K}$ contents as well as $\mathrm{Na} / \mathrm{K}$ ratio:

All salinity levels increased $\mathrm{Na}$ while decreased $\mathrm{K}$ in both shoots and roots of soybean plants (Fig 1). On the other hand, all applied SMs generally increased $\mathrm{K}$ content whereas decreased $\mathrm{Na}$ content in both shoot and roots of soybean plant. Accordingly, $\mathrm{Na} / \mathrm{K}$ ratio was increased due to salinity levels whereas decreased due to SMs treatments. Treatment with AsA was the most efficient treatment for decreasing $\mathrm{Na} / \mathrm{K}$ ratio followed by the treatment with YE.

Yield and yield components

Salinity levels decreased soybean yield estimated as $\mathrm{g} \mathrm{plant}^{-1}$, and $9000 \mathrm{mg} / \mathrm{l}$ was the most damaging level in this respect (Table 5). In addition, seed yield of SMs-treated, salinity-stressed plants was significantly higher compared with untreated plants, though it is still below yield of control plants. So, applied SMs partially counteracted the harmful effect of salinity stress on seed yield of soybean plant.

Table (5): Effect of salinity stress levels and applied SMs as well as their interactions on seed yield $\left(\mathrm{g} \mathrm{plant}^{-1}\right)$ of soybean plants

\begin{tabular}{|l|c|c|c|c|c|c|c|c|}
\hline \multicolumn{1}{|c|}{ Treatments } & \multicolumn{7}{c|}{ Salinity levels (mg/I) (A) } \\
\cline { 2 - 9 } SMs (B) & $\mathbf{3 2 0}$ & $\mathbf{5 0 0 0}$ & $\mathbf{6 0 0 0}$ & $\mathbf{7 0 0 0}$ & $\mathbf{8 0 0 0}$ & $\mathbf{9 0 0 0}$ & Mean \\
\hline Tap water & 13.1 & 7.6 & 6.7 & 6.3 & 4.6 & 3.7 & 7.0 \\
\hline ASA & 21.6 & 11.4 & 10.3 & 9.8 & 9.5 & 8.8 & 11.9 \\
\hline SA & 14.6 & 9.4 & 9.1 & 8.9 & 8.3 & 7.9 & 9.7 \\
\hline SWE & 17.0 & 9.9 & 9.5 & 9.1 & $\wedge .7$ & $\wedge . r$ & $1 . . r$ \\
\hline YE & $19 . \wedge$ & 10.8 & 9.9 & 9.5 & 9.3 & 8.5 & 11.3 \\
\hline Mean & 17.1 & 9.8 & 9.1 & 8.7 & 8.1 & 7.4 & \\
\hline LSD at $5 \%$ & \multicolumn{7}{|c|}{ A: 1.2} & AXB: 3.0 \\
\hline
\end{tabular}

Oil and protein in seeds :

Salinity levels decreased while applied SMs increased both oil (Table 6) and protein (Table 7) percentage in soybean seeds. The highest 
protein percent was obtained in response to AsA treatment followed by YE. Moreover, SMs counteracted the damaging effects of salinity on oil as well as protein percent. The most prominent counteracting effect was due to AsA. Treatment with YE ranked the second in this context.

Table (6): Effect of salinity stress levels and applied SMs as well as their interactions on oil percent in seeds of soybean plants

\begin{tabular}{|c|c|c|c|c|c|c|c|}
\hline \multirow{2}{*}{$\begin{array}{l}\text { Treatments } \\
\text { SMs (B) }\end{array}$} & \multicolumn{7}{|c|}{ Salinity levels $(\mathrm{mg} / \mathrm{l})(\mathrm{A})$} \\
\hline & 320 & 5000 & 6000 & 7000 & 8000 & 9000 & Mean \\
\hline Tap water & 17.83 & 14.17 & IY.AT & $11.7 \varepsilon$ & $1 \cdot . \leqslant 0$ & $1 \cdot . \varepsilon$ & $|Y . V|$ \\
\hline ASA & 11.97 & IV.T. & $I V . \varepsilon Y$ & $1 V .1$. & $17 . \wedge 1$ & 10.1. & IV.rq \\
\hline SA & IN.TY & $17 . V A$ & 17.4. & 10.97 & $1 \leq . V Y$ & $1 \leq .10$ & 17.9 \\
\hline SWE & 11.20 & IV.TY & $17 . V T$ & 17.07 & $10.7 \varepsilon$ & $1 \leq \varepsilon r$ & $17.0 Y$ \\
\hline YE & 11.74 & $1 V .0$. & $17.9 \varepsilon$ & $17 . \%$ & $10 . \wedge \mathrm{V}$ & $1 \leq .7$. & 17.71 \\
\hline Mean & $11 . \varepsilon \varepsilon$ & $17 . \leqslant V$ & 17.4 & 10.09 & $1 \leq . v 1$ & $1 \% .94$ & \\
\hline LSD at $5 \%$ & \multicolumn{7}{|c|}{ A: 1.44} \\
\hline
\end{tabular}

Table (7): Effect of salinity stress levels and applied SMs as well as their interactions on protein percent in seeds of soybean plants

\begin{tabular}{|l|c|c|c|c|c|c|c|}
\hline \multirow{2}{*}{ Treatments } & \multicolumn{7}{|c|}{ Salinity levels (mg/l) (A) } \\
\cline { 2 - 8 } SMs (B) & $\mathbf{3 2 0}$ & $\mathbf{5 0 0 0}$ & $\mathbf{6 0 0 0}$ & $\mathbf{7 0 0 0}$ & $\mathbf{8 0 0 0}$ & $\mathbf{9 0 0 0}$ & Mean \\
\hline Tap water & 37.4 & 33.9 & 33.3 & 32.8 & 31.6 & 30.2 & 33.2 \\
\hline ASA & 39.8 & 36.3 & 35.8 & 35.6 & 35.3 & 35.0 & 36.3 \\
\hline SA & 38.2 & 35.5 & 35.2 & 34.9 & 34.5 & 34.1 & 35.4 \\
\hline SWE & $r 9 . \cdot$ & $r 0.9$ & $r 0.7$ & $r 0 . r$ & $r \varepsilon . \wedge$ & $r \varepsilon . r$ & $r 0 . \wedge$ \\
\hline YE & $r 9 . \varepsilon$ & 36.0 & 35.7 & 35.4 & 35.0 & 34.5 & 36.0 \\
\hline Mean & 38.8 & 35.5 & 35.1 & 34.8 & 34.2 & 33.6 & \\
\hline LSD at 5\% & \multicolumn{7}{|c|}{ B: 1.7} \\
\hline
\end{tabular}

\section{F0 seed's quality parameters}

Salinity stress at all levels decreased whereas SMs increased all soybean seeds quality parameters tested; germination percentage (Table 8), speed of germination (Table 9), seedling dry weight (Table 10), and seedling vigor index (Table 11). The interaction effects between salinity and SMs on seed's quality parameters were significant, where all applied SMs enhanced all seeds quality parameters of plants grown under salinity stress compared with untreated plants hence, used SMs partially counteracted the harmful effect of salinity stress on seed quality parameters of soybean. 
Saker, M. T. et al.

Fig (1): $\mathrm{Na}$ and $\mathrm{K}$ Contents as well as $\mathrm{Na} / \mathrm{K}$ ratio in shoots and roots of soybean plants as affected by Salinity stress levels and applied SMs. 
Table (8): Effect of salinity stress levels and applied SMs as well as their interactions on germination percentage of F0's soybean seeds.

\begin{tabular}{|c|c|c|c|c|c|c|c|}
\hline \multirow{2}{*}{$\begin{array}{l}\text { Treatments } \\
\text { SMs (B) }\end{array}$} & \multicolumn{7}{|c|}{ Salinity levels (mg/l) (A) } \\
\hline & 320 & 5000 & 6000 & 7000 & 8000 & 9000 & Mean \\
\hline Tap water & 80 & 41 & 39 & 35 & 31 & 29 & 42.5 \\
\hline ASA & 19 & 78 & 75 & 74 & 72 & 70 & 76.3 \\
\hline SA & 11 & 52 & 50 & 47 & 44 & 43 & 52.8 \\
\hline SWE & $\wedge \varepsilon$ & vo & VY & $v \cdot$ & 71 & 10 & VT.r \\
\hline YE & 17 & 76 & 73 & 71 & 70 & 67 & 73.8 \\
\hline Mean & 84.0 & 64.4 & 61.8 & 59.4 & 57.0 & 54.8 & \\
\hline LSD at $5 \%$ & & & A: 5 & AXB: 8 & $B$ : & & \\
\hline
\end{tabular}

Table (9): Effect of salinity stress levels and applied SMs as well as their interactions on speed of germination of F0's soybean seeds.

\begin{tabular}{|c|c|c|c|c|c|c|c|}
\hline \multirow{2}{*}{ SMs (B) } & \multicolumn{7}{|c|}{ Salinity levels (mg/l) (A) } \\
\hline & 320 & 5000 & 6000 & 7000 & 8000 & 9000 & Mean \\
\hline Tap water & 40.6 & 23.6 & 22.4 & 21.6 & 18.7 & 15.9 & 23.8 \\
\hline ASA & $\sum \wedge .0$ & 39.5 & 37.6 & 36.2 & 35.2 & 32.2 & 38.2 \\
\hline SA & $\varepsilon r$. & 32.3 & 31.2 & 28.2 & 25.4 & 23.6 & 30.6 \\
\hline SWE & $\leqslant 0.0$ & r4.Y & $r \varepsilon . Y$ & r.r. & $r \wedge$. & $r \leqslant .7$ & 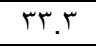 \\
\hline YE & $\varepsilon V . r$ & 37.7 & 35.6 & 33.4 & 30.6 & 27.9 & 35.4 \\
\hline Mean & $\leqslant 0$. & 33.9 & 32.2 & 30.1 & 27.6 & 24.8 & \\
\hline LSD at $5 \%$ & \multicolumn{7}{|c|}{ Salinity: 5.6} \\
\hline
\end{tabular}

Table (10): Effect of salinity stress levels and applied SMs as well as their interactions on dry weight of 10 seedlings $(\mathrm{g})$ resulting from germination of FO's soybean seeds.

\begin{tabular}{|c|c|c|c|c|c|c|c|}
\hline \multirow{2}{*}{\begin{tabular}{|l} 
Treatments \\
SMs (B)
\end{tabular}} & \multicolumn{7}{|c|}{ Salinity levels (mg/l) (A) } \\
\hline & 320 & 5000 & 6000 & 7000 & 8000 & 9000 & Mean \\
\hline Tap water & 0.338 & 0.231 & 0.226 & 0.218 & 0.189 & 0.170 & 0.228 \\
\hline ASA & $.0 Y \leqslant$ & 0.328 & 0.316 & 0.292 & 0.273 & 0.241 & 0.329 \\
\hline SA & 0.361 & 0.290 & 0.283 & 0.266 & 0.250 & 0.224 & 0.279 \\
\hline SWE & . TAY & 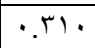 & $\cdot . q^{\prime}$ &.$r \wedge$ &. YTY & $\cdot Y r \varepsilon$ &.$Y 94$ \\
\hline YE & $\cdot . \leqslant 7 \uparrow$ & 0.321 & 0.304 & 0.288 & 0.270 & 0.239 & 0.315 \\
\hline Mean & 0.415 & 0.296 & 0.284 & 0.269 & 0.249 & 0.222 & \\
\hline LSD at $5 \%$ & \multicolumn{7}{|c|}{ A: 0.039} \\
\hline
\end{tabular}


Table (11): Effect of salinity stress levels and applied SMs as well as their interactions on seedling vigor index of seedlings resulting from germination of F0's soybean seeds.

\begin{tabular}{|c|c|c|c|c|c|c|c|}
\hline Treatments & \multicolumn{7}{|c|}{ Salinity levels (mg/l) (A) } \\
\hline SMs (B) & 320 & 5000 & 6000 & 7000 & 8000 & 9000 & Mean \\
\hline Tap water & $r V_{.} \cdot$ & 9.0 & ᄉ.^ & V.7 & 0.1 & $\varepsilon .9$ & $1 \cdot .7$ \\
\hline ASA & $\leqslant 7.7$ & TY.T & Tr.V & Y1.7 & $19 . \mathrm{V}$ & 17.1 & ro.1 \\
\hline$S A$ & rq. & 10.1 & $1 \leq . Y$ & $1 T .0$ & 11. & 9.7 & $10 . \mathrm{r}$ \\
\hline SWE & r. & TT.Y & $r \cdot . \wedge$ & 19.7 & $1 V .1$ & $10 . Y$ & YI.0 \\
\hline $\mathrm{YE}$ & $\varepsilon \cdot, r$ & $r \leqslant . \varepsilon$ & YY.Y & $r \cdot . \varepsilon$ & 11.9 & 17. & rT.V \\
\hline Mean & ro.1 & 11.9 & 18.9 & 17.2 & $1 \leqslant . V$ & 14.0 & \\
\hline LSD at $5 \%$ & \multicolumn{7}{|c|}{ A: 2.7} \\
\hline
\end{tabular}

\section{DISCUSSION}

\section{Salinity stress responses}

Results of the current study indicated that salinity stress not only reduced soybean yield and altered the plant biochemical constituents of FO plants, but also negatively affected germinability of its seeds as well as establishment and development of the F1 generation; indicating a resulting stress on soybean plants. Reduction of yield is the most significant aspect of salt stress in agriculture, to the extent that relative yield under salinity stress conditions was considered as an index for the plant's salinity tolerance (Hasanuzzaman et al., 2013). Yield and its components was significantly reduced in salt-stressed Vigna radiata (Nahar and Hasanuzzaman, 2009). Salinity-induced reduction in plant yield may be due to a reduction in photosynthetically-active green foliage (Wahid et al., 1997). Reduced pollen viability and consequently seed set under salinity stress conditions may also contribute to salinity-induced reduction in crop yield (Abdullah et al., 2001).

Within salinity-induced metabolic alternations recorded in the present investigation, noteworthy was its effect on $\mathrm{Na}$ and $\mathrm{K}$ contents as well as the ratio between them in the plant organs (Fig 1) which may be considered a principal component of the stress imposed on soybean plants by salinity. Increasing $\mathrm{Na}$ at the expense of $\mathrm{K}$ has a dual effect of $\mathrm{Na}$ toxicity and malfunctions of various processes due to $K$ deficiency. $\mathrm{Na}$ displaces $\mathrm{K}$ on binding sites essential for cellular functions (Munns 2002). Na-induced $\mathrm{K}$ deficiency interferes with stomatal functions which ultimately lead to water loss. $\mathrm{Na}$ also competes with $\mathrm{NH}_{4}$ whereas $\mathrm{Cl}$ competes with $\mathrm{NO}_{3}$ which ultimately lead to reduced $\mathrm{N}$ uptake which may account for the reduced seed's protein content recorded in the present investigation. On the other hand, reduced seed oil content may be due a reduction in photosynthetic activities induced by a reduction in either carbon metabolism or photophosphorylation under salinity ( Sudhir and Murthy, 2004).

The accumulation of phenols, proline and ascorbic acid due to salinity was recorded in the present study. Induction of phenols (Chernane et al., 2015), proline (Abdel Aziz et al., 2011; Farouk, 2011), and ascorbic acid 
(Agarwal and Shaheen , 2007 ) was reported in plants exposed to salt stress. Several functions are proposed for the accumulation of proline in tissues submitted to salt stress: 1) osmotic adjustment, 2) detoxification of excess ammonia, 3) stabilization of proteins and/or membranes, 4) scavenger of free radicals and 5) stability of some cytoplasmic and mitochondrial enzymes (Ozdemir et al. 2004). Phenolic compounds retard or inhibit lipid autoxidation by acting as radical scavengers (Namiki, 1990) and, consequently, are essential antioxidants that protect against propagation of the oxidative chain. Ascorbic acid reacts with a range of ROS such as ${ }^{1} \mathrm{O}_{2}$, $\mathrm{O}_{2}^{--}, \mathrm{HO}^{\circ}$ and $\mathrm{H}_{2} \mathrm{O}_{2}$, which is the basis of its antioxidant action (Shigeoka et al., 2002 ; Foyer, 2004) .

Effects of SM on alleviating salinity stress:

Results of the present investigation indicated that all SMs tested altered the metabolism of salt-stressed plants by elevating their contents from AsA, proline and phenols and maintained the $\mathrm{Na} / \mathrm{K}$ ratio that has been disturbed due to salinity stress. These SMs effects mitigated salinity stress on plants hence, maintained their yield as well as its quality and contributed to a more vigorous F1 generation, substantiating the hypothesis on which the study is founded. Utilization of AsA, SA. SWE and YE as stress mitigators and the mode of action of their alleviative effects will be discussed as follows:

\section{Effects of AsA}

Utilization of AsA as a stress mitigator is well-established. It has been recorded that endogenous AsA content increases under salinity stress conditions (Agarwal and Shaheen, 2007). Accordingly, AsA was applied exogenously to alleviate drought stress on Hibiscus esculentus (Amin et al., 2009) and to counteract salinity stress effects on Glycine max (Dehghan et al., 2011). It functions as a reductant for many free radicals, thereby minimizing the damage caused by oxidative stress. AsA is an important antioxidant which reacts with a range of ROS such as ${ }^{1} \mathrm{O}_{2}, \mathrm{O}_{2}{ }^{--}, \mathrm{HO}$ and $\mathrm{H}_{2} \mathrm{O}_{2}$, constituting the basis of its antioxidant action (Shigeoka et al., 2002 ; Foyer, 2004 ). On the other hand, AsA has been implicated in several types of biological activities in plants; 1) as an enzyme co-factor, 2) as an antioxidant and 3) as a donor/acceptor in electron transport at the plasma membrane or in the chloroplasts, all of which are related to oxidative stress resistance (Conklin, 2001). An essential route for ROS-scavenging by AsA occurrs near $\mathrm{PSI}$, thereby minimizing the risk of escape and reaction of ROS with each other (Foyer and Noctor, 2000). Evidences from current study supported from relevant literature indicate that the alleviative effects of AsA against salt stress is based on enhanced antioxidant capacity (Athar et al., 2008), especially its enzymatic component by elevating the activities of CAT and POD (Munir and Aftap, 2011) as well as CAT, POD and SOD (Dehghan et al., 2011), preserving chlorophyll biosynthesis and marinating photosynthetic activities (Hamada and Al-Hakimi, 2009) and accumulation of compatible solutes including proline (Azzedine et al., 2011).

\section{Effects of SA}

Previous studies revealed a significant role of $S A$ in plant stress responses. Exogenous application of SA through rooting medium modulates 
ion accumulation and antioxidant activity in salt-stressed spring wheat, conferring salinity tolerance (Arfan, 2009). In addition, supplementation of SA counteracted drought stress effects on Nigella sativa (Kabiri et al., 2014). Stress alleviative effects of $S A$ is mediated through enhancing both components of the plant's antioxidant system; the enzymatic component ( ElTayeb, 2005; Arfan, 2009) as well as the nonenzymatic component (Srivastava and Dwivedi, 1998) and accumulation of compatible osmolytes (Kabiri et al., 2014), especially proline (Arfan, 2009). The accumulation of inorganic or organic osmolytes makes the surplus of water uptake possible as evidenced by increased relative water contents in tissues of SA-pretreated plants (Szepesi et al. 2005). Improved photosynthetic performance of plants under stress conditions due to SA application (Ananieva et al. 2004) is another element of its stress-mitigation effect, which suggest that SApretreatment may improve the gross rate of carbon assimilation during osmotic stress. SA-dependent hormonal regulation during salt stress conditions manifested by maintaining IAA and cytokinin contents, that otherwise diminish under stress, and thus reduce stress-induced inhibition of plant growth as well as preserving a high ABA level providing the development of anti-stress reactions (Shakirova et al. 2003).

\section{Effects of SWE}

In accordance with the results of the present investigation, SWE of Ulva rigida enhanced salt stress tolerance of wheat via activation of the enzymatic antioxidant system (SOD, CAT and APX) as well as accumulation of total phenolics, leading to enhanced growth of salt-affected, SWE-treated plants (Chernane et al., 2015). In addition, extracts of two seaweeds, Fucus spiralis and Ulva rigida enhanced drought stress tolerance of Phaseolus vulgaris through modulating the plant's antioxidant system and the contents of some key plant osmoprotectants (Mansori et al., 2014). SWE has been assigned an immune-modulating properties due to its constituents from antioxidants, vitamins, carotenoids, polysaccharides, phycobiliproteins (Abd El-Baky et al., 2008).

SWE can alleviate the harmful effect of salinity stress through its effects on: 1) activation of root cells and their cytokinins biosynthetic capacity (Schmidt, 2005), 2) enhancing leaf water status (Demir et al., 2004), 3) altering hormonal balances and favor cytokinins and auxins production (Schmidt, 2005), 4) enhancement of antioxidant enzymes (Schmidt, 2005), 5) stimulating biosynthesis of tocopherols, ascorbic acid and carotenoids which protect PSII photosynthetic apparatus (Zhang and Schmidt, 2000) and 6) Stimulation of chloroplast development, enhancing phloem loading and delay senescence (Demir et al., 2004 ).

\section{Effects of YE}

YE Extract is a biostimulant that had been used to sustain plant growth and yield in stressful conditions. It has been applied to enhance drought tolerance in Phaseolus vulgaris (Ibrahim, 2014) and wheat (Hammad and Ali, 2014). Stress alleviation effect of YE may be ascribed to its biostimulants, being a rich source of phytohormones (especially cytokinins), vitamins, enzymes, amino acids and minerals (Khedr and Farid, 2000 ; Mahmoud, 
2001). Its cytokinins content have specially been implicated for its beneficial role during stress (Barnett, et al., 1990).

\section{CONCLUSIONS}

Ascorbic acid, Salicylic acid, seaweed extract and yeast extract partially restored salinity-induced decrease in seed yield of salt-stressed soybean plants, with the first and the latter were the most effective in this respect. Results indicated that the alleviative effect of the these tested stress modulators was based on elevating the levels of endogenous ascorbic acid, total phenols and proline whereas decreasing the ratio between $\mathrm{Na}$ and $\mathrm{K}$ in salt-stressed plants. In addition, results indicated that the alleviative effect of the applied stress mitigators was evident not only on salt-stressed plants but also on their descendant seeds where their germination, vigour, and seedling establishment were enhanced

\section{REFERENCES}

Abdel Aziz, N.G.; Mahgoub, M.H. and Siam, H.S. (2011). Growth, flowering and chemical constituents performance of Amaranthus tricolor plants as influenced by seaweed (Ascophyllum nodosum) extract application under salt stress conditions. J. Appl. Sci. Res., 7: 1472-1484.

Abd El-Baky, H.H.; El Baz, F.K. and El-Baroty, G.S. (2008). Evaluation of marine alga Ulva lactuca $\mathrm{L}$. as a source of natural preservative ingredients. Electronic J. Environ. Agric. Food Chem., 7: 3353-3367.

A. O. A. C., (1980). Official Methods of Analysis" Association of Official Agricultural Chemists, $13^{\text {th }}$ Ed. Washington, D.C., USA.

Abdullah, Z.; Khan, M.A. and Flowers, T.J. (2001). Causes of sterility in seed set of rice under salinity stress. J. Agron. Crop Sci., 167:25-32.

Agarwal, S., and Shaheen, R. (2007). Stimulation of antioxidant system and lipid peroxidation by abiotic stresses in leaves of Momordica charantia . Braz. J. Plant Physiol., 19:149-161.

Amin, B.; Mahleghah, G.; Mahmoud, H.M.R. and Hossein, M. (2009). Evaluation of interaction effect of drought stress with ascorbate and salicylic acid on some of physiological and biochemical parameters in Okra (Hibiscus esculentus L.). Res. J. Biol. Sci., 4: 380-387.

Ananieva,K .; Malbeck, J.; Kamínek,J. and van Staden,J. (2004). Methyl jasmonate down-regulates endogenous cytokinin levels in cotyledons of Cucurbita pepo (zucchini) seedlings. Physiol. Plant., 122: 496 - 503.

Arfan, M. (2009). Exogenous application of salicylic acid through rooting medium modulates ion accumulation and antioxidant activity in spring wheat under salt stress. Int. J. Agric. Biol., 11: 437-442.

Arfan, M.; Athar, H.R. and Ashraf, M. (2006). Does exogenous application of salicylic acid through the rooting medium modulate growth and photosynthetic capacity in two differently adapted spring wheat cultivars under salt stress? . J. Plant Physiol., 164: 685-694. 
Athar, H.R.; Khan, A. and Ashraf, M. (2008). Exogenously applied ascorbic acid alleviates salt-induced oxidative stress in wheat. Environ. Exp. Bot., 63:224-231.

Azzedine, F.; Gherroucha, H. and Baka, M. (2011). Improvement of salt tolerance in durum wheat by ascorbic acid application. J Stress Physiol. Biochem., 7:27-37.

Barnett, J.A.; Payne, R.W. and Yarrow, D. (1990). Yeasts: characteristics and Identification. Cambridge University Press, London, pp: 999.

Bates, S.; Waldern, R .P. and Teare, D. (1973). Raid determination of free proline for water stress studies .Plant and Soil, 39: 205-207.

Chernane, H.; Latique, S.; Mansori, M. and El Kaoua, M. (2015). Salt stress tolerance and antioxidative mechanisms in wheat plants (Triticum durum L.) by seaweed extracts application. IOSR J. Agric. Veter. Sci., 8: 36-44.

Conklin, P. (2001). Recent advances in the role and biosynthesis of ascorbic acid in plants. Plant, Cell and Environ, 24:383- 394.

Dehghan, G.; Rezazadeh, L. and Habibi, G. (2011). Exogenous ascorbate improves antioxidant defense system and induces salinity tolerance in soybean seedlings. Acta Biol. Szeged., 55:261-264.

Demir, D.; Günes, A.; Inal, A. and Alpaslan, M. (2004). Effects of humic acids on the yield and mineral nutrition of cucumber (Cucumis sativus L.) grown with different salinity levels. Acta hort., 492: 95-104.

El Tayeb, M.A. (2005). Response of barley grains to the interactive effect of salinity and salicylic acid. Plant Growth Regul., 45:215-224.

Farouk, S. (2011). Ascorbic acid and a -Tocopherol minimize salt-induced wheat leaf senescence. J. Stress Physiol. Biochem., 7:58-79.

Foyer (2004) The role of ascorbic acid in defense networks and signaling in plants. In: H. Asard (ed.) Vitamin C: its function and biochemistry in animals and plants. Garland Science/BIOS Scientific Publishers, London/New York, pp 73-91.

Foyer, C.H. and Noctor, G. (2000). Oxygen processing in photosynthesis: regulation and signaling. New Phytol., 146: 359-388.

Gehad, A. (2003). Deteriorated Soils in Egypt: Management and Rehabilitation. Executive Authority for Land Improvement Projects (EALIP). Ministry of agricultur and land reclamation. Egypt.

Gomez, K. A. and Gomez, A. A. (1984). Statistical procedures for agricultural research $.2^{\text {nd }} E d$., Willy and Sons, New York. U.S.A.

Hamada, A.M. and Al-Hakimi, A.M. (2009). Exogenous ascorbic acid or thiamine increases the resistance of sunflower and maize plants to salt stress. Acta Agron. Hung., 57:335-347.

Hammad, S.A.R. and Ali, O.A.M (2014). Physiological and biochemical studies on drought tolerance of wheat plants by application of amino acids and yeast extract. Annals of Agric. Sci, 59: 133-145.

Hasanuzzaman , M; Nahar, K. and Fujita, M. (2013). Plant Response to Salt Stress and Role of Exogenous Protectants to Mitigate Salt-Induced Damages. In Ecophysiology and responses of plants under salt stress (Eds P. Ahmad, M.M. Azooz, M.N.V. Prasad). Springer Public., ISBN: 978-1-4614-4746-7. 
Ibrahim, M.F.M. (2014). Induced drought resistance in common bean (Phaseolus vulgaris L.) by exogenous application with active yeast suspension. Middle East J. Appl. Sci., 4: 806-815.

ISTA (International Seed Testing Association) (1999). International Rules for Seed Testing. Rules 1999. Seed Sci. Technol.(Suppl.),24 : 1-335.

Jackson, M.L. (1967). Soil chemical analysis. Prentice Hall of India, Ltd., New Delhi.

Kabiri, R.; Nasibi, F. and Farahbakhsh, H. (2014). Effect of exogenous salicylic acid on some physiological parameters and alleviation of drought stress in Nigella sativa plant under hydroponic culture. Plant Protec. Sci., 50: 43-51.

Khedr, Z.M.A. and Farid, S. (2000). Response of naturally virus infected tomato plants to yeast extract and phosphoric acid application. Annals of Agric. Sci., Moshtohor, 38(2): 927-939.

Mahmoud, T.R.( 2001). Botanical studies on growth and germination of Magnolia (Magnolia grandiflora L.) Plants. M.Sc. Thesis, Fac. Agric., Moshtohor, Zagazig Univ., $103 \mathrm{pp}$.

Mansori, M.; Chernane, H.; Latique, S.; Benaliat, A.; Hsissou, D. and El Kaoua, M. (2014). Saweed extract effect on water deficit and antioxidative mechanisms in bean plants (Phaseoulus vulgaris L.). J. Appl. Phycol., 27: 1689-1698.

Munir N, Aftab F (2011) Enhancement of salt tolerance in sugarcane by ascorbic acid pretreatment. Afr. J. Biotechnol 10:18362-18370

Munns R (2002) Comparative physiology of salt and water stress. Plant Cell Environ 25:239-250

Nahar K, Hasanuzzaman M (2009) Germination, growth, nodulation and yield performance of three mungbean varieties under different levels of salinity stress. Green Farming 2:825-829

Namiki. M. (1990). Antioxidants / antimutagens in food. CRC Critical Reviews in Food Science and Nutrition, 29, 273-300

on the acclimation of tomato plants to salt- and osmotic stress. Volume 49

Ozdemir, O., Melike, B. Tijen, D. and Ismail, T. ( 2004). Effects of 24epibrassinolide on seed germination, seedling growth, lipid peroxidation, proline content and antioxidative system of rice (Oryza sativa L.) under salinity stress. Plant growth regulation. 42: 203-211.

Parvaiz A., Satyawati S. (2008): Salt stress and phytobiochemical responses of plants - a review. Plant Soil Environ., 54: 89-99.

Peterburgski, A. V. (1968). Handbook of Agronomic chemistry. Klop Publishing House Moscow .pp: 29- 86.

Piper, C.S. (1950). Soil and plant analysis. Inter. Sci. Publ. Inc., New York.

Ranganna, C. (1979). Manual of analysis of fruit vegetable products. $2^{\text {nd }}$ ed. Tata McGraw Hill Publishing Company limited New Delhi.

Schmidt, R.E. ( 2005). biostimulants function in turfgrass nutrition. Ph.D. Emeritus Virginia Tech. 
Shakirova, F.M., Sakhabutdinova, A. R., Bezrukova, M. V., Fathudinova, R. A. and Fathutdinova, D. R. (2003). Changes in hormonal status of wheat seedlings induced by Salicylic acid and salinity. Plant Sci., 164: 317-322.

Shigeoka S, Ishikawa T, Tamoi M, Miyagawa $\mathrm{Y}$, Takeda T, Yabuta $\mathrm{Y}$, Yoshimura K. (2002). Regulation and function of ascorbate peroxidase isoenzymes. J. Exp. Bot., 53:1305-1319.

Srivastava, M.K. and Dwivedi, U.N. (1998): Salicylic acid modulates glutathione metabolism in pea seedlings. J. Plant Physiol. Molec. Biol., 43: 439-463.

Sudhir, P. and Murthy, S.D.S. (2004). Effects of salt stress on basic processes of photosynthesis. Photosynthetica, 42:481-486.

Szepesi, A., Csisar, J. and Baikan, S. et al. (2005). Role of salicylic acid pretreatment on the acclimation of tomato plants to salt- and osmotic stress. Acta Biol Szeged 49:123-125.

Toivonen, P.M.A. and Stan, S. (2004). The effect of washing on physiochemical changes in packaged, sliced green peppers. Int. J. Food Sci. Technol. 39: 43-51.

Wahid, A.; Rao, R. and Rasul, E. (1997). Identification of salt tolerance traits in sugarcane lines. Field Crop Res., 54:9-17.

Zhang X. and Schmidt, R.E. (1999). Antioxidant response to hormonecontaining products in Kentucky bluegrass subjected to drought. Crop Sci., 39:545-551.

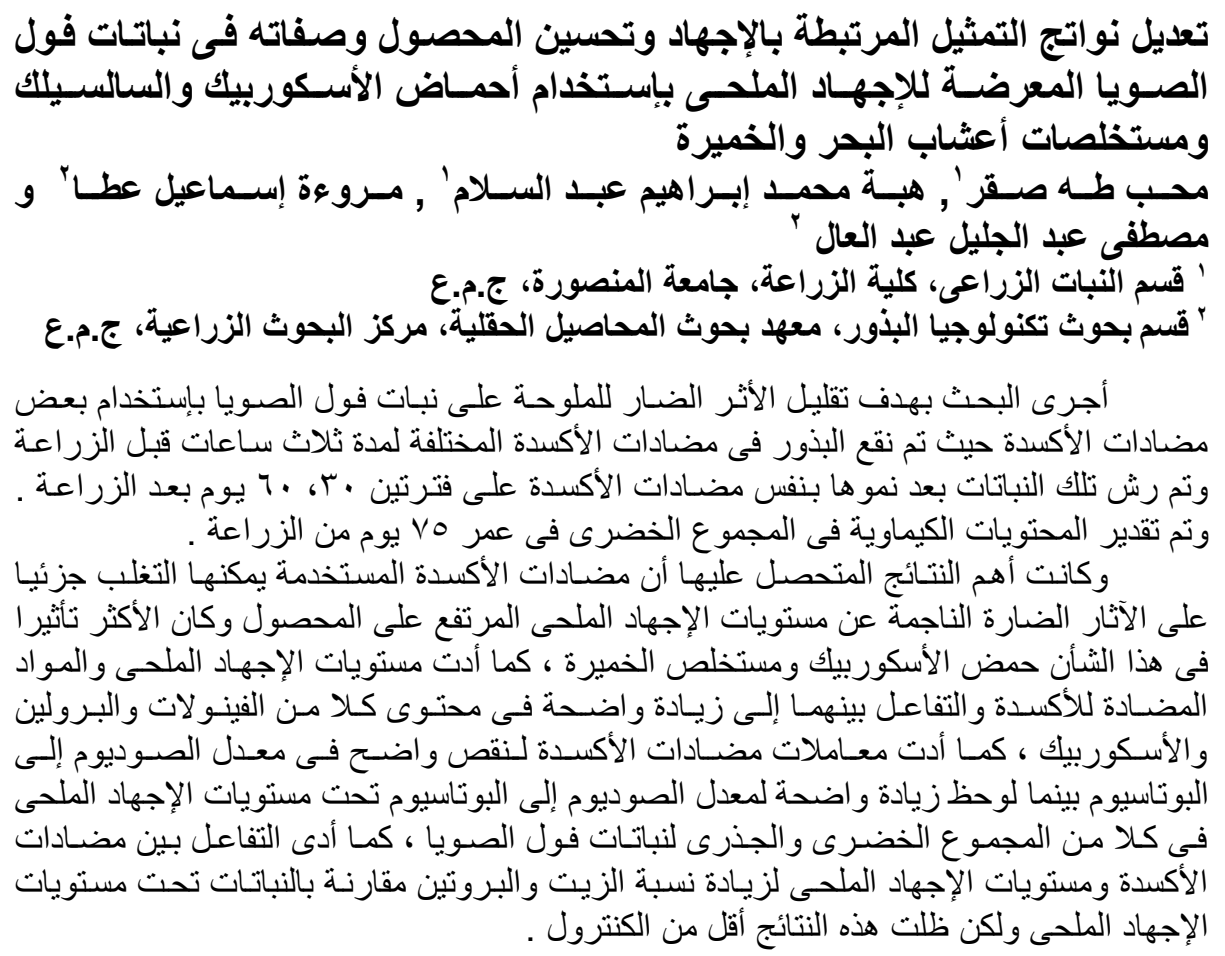

